\title{
EFFECT OF POTASSIUM SOURCES ON THE ANTIOXIDANT ACTIVITY OF EGGPLANT ${ }^{(1)}$
}

\author{
Douglas José Marques $^{(2)}$, Fernando Broetto ${ }^{(3)}$, Mozart Martins Ferreira ${ }^{(4)}$, Allan Klynger \\ da Silva Lobato ${ }^{(5)}$, Fabricio William de Ávila ${ }^{(6)} \&$ Fabricio José Pereira ${ }^{(7)}$
}

\begin{abstract}
SUMMARY
Potassium participates in the essential processes in plant physiology, however, the effects of $\mathrm{K}$ sources on plant metabolism have been little studied. Also, in certain cases, $\mathrm{K}$ sources and concentrations may cause undesirable effects, e.g., soil salinization. The objective was to evaluate the effect of $K$ sources and levels on the enzyme activity of the antioxidant system and protein content in eggplant (Solanum melongena $\mathrm{L}$.) leaves and to determine the most suitable $\mathrm{K}$ sources for these physiological characteristics. The experiment was conducted in randomized blocks, in a $2 \times 4$ factorial design, consisting of two $\mathrm{K}$ sources $\left(\mathrm{KCl}\right.$ and $\left.\mathrm{K}_{2} \mathrm{SO}_{4}\right)$ and rates $(250$, 500,750 , and $1000 \mathrm{~kg} \mathrm{ha}^{-1} \mathrm{~K}_{2} \mathrm{O}$ ), with four replications. The following variables were evaluated: plant height, number of leaves per plant, superoxide dismutase (SOD), catalase (CAT), and leaf protein content. There was an increase in CAT activity with increasing $\mathrm{K}$ levels until 30 days after transplanting (DAT), when $\mathrm{K}_{2} \mathrm{SO}_{4}$ was applied and until $60 \mathrm{DAT}$, when $\mathrm{KCl}$ was used; after this period, the enzyme activity decreased under both sources. The activity of SOD increased in the presence of $\mathrm{KCl}$, but was reduced with the application of $\mathrm{K}_{2} \mathrm{SO}_{4}$. For both $\mathrm{K}$ sources, increasing rates reduced the protein content and number of leaves per plant, and this reduction was greater under $\mathrm{KCl}$ application. Thus it was concluded that $\mathrm{KCl}$ tends more strongly to salinize the soil than $\mathrm{K}_{2} \mathrm{SO}_{4}$. Both for $\mathrm{KCl}$ and for $\mathrm{K}_{2} \mathrm{SO}_{4}$, the increasing rates adversely affected the activities of CAT and SOD and the levels of leaf protein in eggplant. The potential of $\mathrm{KCl}$ to reduce the enzyme activity of SOD and CAT, leaf protein content and plant growth of eggplant was stronger than that of $\mathrm{K}_{2} \mathrm{SO}_{4}$.
\end{abstract}

Index terms: Solanum melongena L., potassium, superoxide dismutase, catalase, protein.

(1) Part of the Master's thesis of the first author. Received for publication on October 2, 2013 and approved on July $25,2014$.

(2) Professor, Universidade José do Rosário Vellano - UNIFENAS. Campus Rod. MG, 179, km 0. CEP 37130-000 Alfenas (MG), Brasil. E-mail: douglasjmarques81@yahoo.com.br

(3) Professor, Universidade Estadual Paulista, Campus de Botucatu. Distrito de Rubião Júnior, s/n. CEP 18618-970 Botucatu (SP), Brasil. E-mail: broetto@ibb.unesp.br

(4) Professor, Departamento de Ciência do Solo, Universidade Federal de Lavras - UFLA. Caixa Postal 3037. CEP $37200-000$ Lavras (MG), Brasil. E-mail: mozartmf@ufla.br

(5) Professor, Universidade Federal Rural da Amazônia. Av. Presidente Tancredo Neves, 2501, Bairro Montese. CEP 66077-901 Paragominas (PA), Brasil. E-mail: allanllobato@yahoo.com.br

(6) Professor, Universidade Estadual do Centro-Oeste-UNICENTRO. Rua Simeão Camargo Varela de Sá, 03, Vila Carli. CEP 85040-080 Guarapuava (PR), Brasil. E-mail: fabriciowilliamavila@yahoo.com.br

(7) Professor, Departamento de Biologia, UFLA. E-mail: fabriciopereira@dbi.ufla.br 


\title{
RESUMO: FONTES POTÁSSICAS ALTERANDO A ATIVIDADE ANTIOXIDANTE DA BERINJELA
}

\begin{abstract}
O potássio participa dos processos essenciais na fisiologia da planta; contudo, os efeitos de fontes potássicas no metabolismo das plantas têm sido pouco estudados. Além disso, diferentes fontes e concentrações de K podem levar a efeitos indesejados como a salinização do solo. Dessa forma, objetivou-se avaliar o efeito de fontes e doses de K sobre a atividade de enzimas do sistema antioxidante e o teor de proteinas em folhas de berinjela, bem como qual das fontes de K pode ser mais adequada em razão dessas características fisiológicas (Solanum melongena $L$.). O experimento foi conduzido em blocos casualizados e esquema fatorial $2 \times 4$,

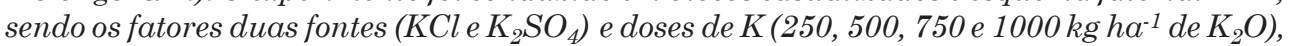
com quatro repetições. As variáveis avaliadas foram: altura das plantas, número de folhas por planta, atividade da superóxido dismutase (SOD), catalase (CAT) e teor foliar de proteína. Observou-se aumento na atividade da CAT com a elevação das doses de Katé os 30 dias após o transplante $(\mathrm{DAT})$ para $\mathrm{K}_{2} \mathrm{SO}_{4}$ e até $60 \mathrm{DAT}$ para $\mathrm{KCl}$; após esse período a atividade da enzima reduziu em ambas as fontes. A atividade da SOD aumentou na presença do $\mathrm{KCl}$, mas reduziu com a aplicação do $\mathrm{K}_{2} \mathrm{SO}_{4}$. Para ambas as fontes de $\mathrm{K}$, o aumento das doses promoveu redução no teor de proteínas e no número de folhas das plantas, sendo essa redução maior com a utilização do KCl. Dessa forma, concluiu-se que o KCl apresentou maior poder de salinização do solo em comparação ao $\mathrm{K}_{2} \mathrm{SO}_{4}$. Tanto para $\mathrm{KCl}$ quanto para $\mathrm{K}_{2} \mathrm{SO}_{4}$, a elevação das doses influenciou negativamente as atividades da CAT e SOD e os teores de proteina foliares em berinjela. $\mathrm{O} \mathrm{KCl}$ apresentou maior potencial de redução das atividades das enzimas SOD $e$ CAT dos teores foliares de proteinas e do desenvolvimento das plantas de berinjela.
\end{abstract}

Termos de indexação: Solanum melongena L., potássio, superóxido dismutase, catalase, proteina.

\section{INTRODUCTION}

Plants have a high requirement for $\mathrm{K}$ and one of the reasons is the need to maintain a high $\mathrm{K}$ content in the cytoplasm, mainly to ensure enzyme activity (Malavolta, 2006). Another reason is that K in cytosol and chloroplast stroma is required at high concentrations to maintain anion neutralization and an appropriate $\mathrm{pH}$ level for cell functioning (Marschner, 1995). Also, $\mathrm{K}$ can participate in the control of stomatal opening and closing which is essential for photosynthesis (Steineck \& Haeder, 1978). Despite its importance, excess K reduces the soil osmotic potential, making the soil saline, resulting in a modified soil in which the growth of most species is prejudiced by the presence of high concentrations of soluble salts, exchangeable $\mathrm{Na}$, or both in the rhizosphere (SSSA, 2008).

Among the potash mineral fertilizers available on the Brazilian market, potassium chloride $(\mathrm{KCl})$ is the most popular, due to the abundant supply and best value for money. Aside from $\mathrm{KCl}$, potassium sulfate $\left(\mathrm{K}_{2} \mathrm{SO}_{4}\right)$ and potash and magnesium sulphate $\left(\mathrm{K}_{2} \mathrm{SO}_{4} \cdot 2 \mathrm{MgSO}_{4}\right)$, other $\mathrm{K}$ sources are widely used in different agricultural segments in Brazil (Ernani et al., 2007). These $\mathrm{K}$ sources induce different salinity levels in the soil; for example, $\mathrm{KCl}$ has a higher salt content than $\mathrm{K}_{2} \mathrm{SO}_{4}$ (Kamburova \& Kirilov, 2008). However, there are no studies that prove the higher efficiency of this source for eggplant. In the case of some vegetables, e.g., potato and eggplant, $\mathrm{KCl}$ application has resulted in lower yields compared to potassium sulfate (Wuzhong, 2002).
Salinity can restrict the absorption of water and nutrients, reduce photosynthetic processes and increase respiration, inducing a reduction in plant growth (Khadri et al., 2006). In the case of water deficit, the activity of the enzyme system and the production of compounds related to the antioxidant system of plants are altered (Chaves et al., 2002). This plant response occurs due to excessive accumulation of reactive oxygen species (ROS) in plant cells, in particular of superoxide, hydroxyl radical and hydrogen peroxide (Moller et al., 2007). Salinity can promote an intense ROS production that can lead to the degradation of proteins and membranes, reducing photosynthesis and plant growth (Bose et al., 2014). Among the enzymatic mechanisms involved in detoxification of ROS, there are the isoforms of the enzyme superoxide dismutase (SOD), catalase (CAT), ascorbate peroxidase (APX), and peroxidase phenols (POX). Superoxide dismutase acts by converting $\mathrm{O}_{2}{ }^{-}$ into $\mathrm{H}_{2} \mathrm{O}_{2}$ and is localized mainly in the mitochondria and chloroplasts. These organelles generate most of the ROS in plant cells (Apel \& Hirt, 2004). Peroxidades and catalases convert $\mathrm{H}_{2} \mathrm{O}_{2}$ into water and molecular oxygen, which are harmless to plants (Moller et al., 2007). Although the salinization leads to the production of ROS, at certain concentrations, K has an effect of reducing the harmful effects of salinization and ROS, mitigating stress effects (Abbasi et al., 2014). This effect has been widely investigated in view of the need to understand its relationship with salinity and stress tolerance better.

Thus, this study aimed to evaluate the effect of $\mathrm{K}$ sources and levels on the development, enzyme activity 
of the antioxidant system and the protein content of eggplants.

\section{MATERIAL AND METHODS}

The experiment was carried out at the Faculty of Agricultural Sciences of the São Paulo State University, Botucatu, SP (lat $22^{\circ} 51^{\prime} \mathrm{S}$, long $48^{\circ} 26^{\prime} \mathrm{W}$; $815 \mathrm{~m}$ asl). The climate was classified as $\mathrm{Cwa}$, according to the international classification of Köppen (Cunha \& Martins, 2009), which is a warm temperate climate with rainy summers and dry winters, at an average temperature below $17^{\circ} \mathrm{C}$ in the coldest month and above $23{ }^{\circ} \mathrm{C}$ in the hottest month. We used eggplant cultivar Embu. The experiment was arranged in a randomized block factorial design with two $\mathrm{K}$ sources $\left(\mathrm{KCl}\right.$ and $\left.\mathrm{K}_{2} \mathrm{SO}_{4}\right) \times$ four $\mathrm{K}_{2} \mathrm{O}$ rates $(250$, 500,750 , and $1000 \mathrm{~kg} \mathrm{ha}^{-1} \mathrm{~K}_{2} \mathrm{O}$ ), with four replications. The $\mathrm{K}_{2} \mathrm{O}$ levels were defined according to recommendations of Raij et al. (1996) for treatments and equivalent $K$ values per pot for eggplant (Table 1 ). Equivalent $\mathrm{K}_{2} \mathrm{O}$ contents per pot were calculated, considering $58 \%$ for $\mathrm{KCl}$ and $44 \%$ for $\mathrm{K}_{2} \mathrm{SO}_{4}$. The soil was classified as a medium-textured Latossolo Vermelho distroférrico (Oxisol) (Embrapa, 1997), containing $615 \mathrm{~g} \mathrm{~kg}^{-1}$ sand, $45 \mathrm{~g} \mathrm{~kg}^{-1}$ silt and $340 \mathrm{~g} \mathrm{~kg}^{-1}$ clay in the $0-20 \mathrm{~cm}$ layer. The soil was sieved (5 $\mathrm{mm}$ ), resulting in a total volume of $32 \mathrm{~L}$, and distributed in plastic pots. The soil chemical characteristics at the beginning of the experiment were the following: $\mathrm{pH}(4.1)$, organic matter $\left(17 \mathrm{~g} \mathrm{dm}^{-3}\right)$, $\mathrm{P}_{\text {resin }}\left(2 \mathrm{mg} \mathrm{dm}^{-3}\right), \mathrm{K}\left(0.2 \mathrm{mmol}_{\mathrm{c}} \mathrm{dm}^{-3}\right), \mathrm{Ca}\left(2 \mathrm{mmol}_{\mathrm{c}} \mathrm{dm}^{-3}\right)$, and $\mathrm{Mg}\left(1 \mathrm{mmol}_{\mathrm{c}} \mathrm{dm}^{-3}\right)$. The calculations for liming and $\mathrm{N}$ and $\mathrm{P}$ base fertilization were based on recommendations of Raij et al. (1996) for eggplant. To increase saturation to $80 \%$, the application of $96 \mathrm{~g}$ dolomitic limestone $(\mathrm{PRNT}=91 \%)$ per pot was required for acidity correction. Nitrogen (3.2 g per pot) was applied in the form of ammonium sulfate and $\mathrm{P}$ (28.2 g per pot) as thermophosphate. Half the

Table 1. Treatments and equivalent $K$ contents per pot, based on two $\mathrm{K}_{2} 0$ sources, $\mathrm{KCl}$ and $\mathrm{K}_{2} \mathrm{SO}_{4}$

\begin{tabular}{|c|c|c|c|c|}
\hline \multirow{2}{*}{ Treatment } & \multicolumn{2}{|c|}{ K source } & \multicolumn{2}{|c|}{ Equivalence in pots } \\
\hline & $\mathrm{KCl}$ & $\mathrm{K}_{2} \mathrm{SO}_{4}$ & $\mathrm{KCl}$ & $\mathrm{K}_{2} \mathrm{SO}_{4}$ \\
\hline & $-\mathrm{kg}$ & $\mathrm{K}_{2} \mathrm{O}-$ & $\longrightarrow$ & 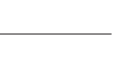 \\
\hline $\mathrm{T} 1$ & 250 & & 6.81 & \\
\hline $\mathrm{T} 2$ & 500 & & 13.63 & \\
\hline T3 & 750 & & 20.44 & \\
\hline $\mathrm{T} 4$ & 1000 & & 27.26 & \\
\hline $\mathrm{T} 5$ & & 250 & & 8.31 \\
\hline $\mathrm{T} 6$ & & 500 & & 16.76 \\
\hline $\mathrm{T} 7$ & & 750 & & 25.14 \\
\hline $\mathrm{T} 8$ & & 1000 & & 33.52 \\
\hline
\end{tabular}

recommended amount was supplied in form of organic fertilization by adding $160 \mathrm{~g}$ of cattle-manure compost per pot, corresponding to $10 \mathrm{t} \mathrm{ha}^{-1}$. Eggplant seedlings were grown in trays with 128 cells, 6.0 to $6.2 \mathrm{~cm}$ high, containing substrate composed of inert and pathogenfree material. The seedlings were planted when they had 3-4 true leaves, about 35 days after sowing.

Topdressing fertilization was initiated 15 days after transplanting (DAT), and repeated fortnightly. The $\mathrm{N}$ source used as topdressing was calcium nitrate of which a total rate of $22.82 \mathrm{~g}$ per pot was split into 14 applications. The pots were arranged in a spacing of $0.63 \mathrm{~m}$ between plants and $1.0 \mathrm{~m}$ between rows. Tensiometers were installed at a depth of $0.20 \mathrm{~m}$ and $0.15 \mathrm{~m}$ away from the plant stem. Irrigation was applied by hand to raise the soil moisture to field capacity, corresponding to a matric potential of approximately -30 kPa. During the experiment, aliquots of the soil solution were collected every seven days. The solution was collected with an extractor installed at a depth of $0.15 \mathrm{~m}, 0.10 \mathrm{~m}$ away from the plant stem. A digital conductivity meter was used to determine electrical conductivity (EC) and the EC readings were corrected based on soil moisture.

The plant height and number of leaves per plant were determined, and plant leaves were collected to assess the enzymatic activity $30,60,90$, and $110 \mathrm{DAT}$. Leaves for enzyme analyses were sampled in triplicate, always at 8:00 AM, in standardized collections in the mid- region of the canopy. The leaf samples were frozen in liquid $\mathrm{N}$ and maintained in an ultrafreezer $\left(-80{ }^{\circ} \mathrm{C}\right)$ until enzymatic analyses. Subsequently, the samples were ground in liquid $\mathrm{N}$ and prepared to obtain extracts for analysis of the activities of superoxide dismutase (SOD), catalase (CAT) and the protein content. Superoxide dismutase (EC 1.15.1.1) was extracted from $300 \mathrm{mg}$ of plant material ground in $3 \mathrm{~mL}$ potassium phosphate buffer at a concentration of $100 \mathrm{mmol} \mathrm{L}^{-1}$ (TFK, $\mathrm{pH}$ 6.8); $0.1 \mathrm{mmol} \mathrm{L}^{-1}$ EDTA; $0.1 \%$ (v/v) 2-mercaptoethanol; $0.1 \%(\mathrm{v} / \mathrm{v})$ Triton X-100; $30 \mathrm{mg}$ polyvinylpyrrolidone (PVP) and $20 \mathrm{mmol} \mathrm{L}^{-1}$ ascorbate. After centrifugation at $15,000 \mathrm{~g}$ for $15 \mathrm{~min}$ at $4{ }^{\circ} \mathrm{C}$, the supernatant was collected for further analysis.

The SOD activity was determined as described by Giannopolitis \& Ries (1977). The reaction medium consisted of $52.5 \mathrm{mmol} \mathrm{L}^{-1}$ TFK (pH 7.8); $0.1 \mathrm{mmol} \mathrm{L}^{-1}$ EDTA; $13 \mathrm{mmol} \mathrm{L}^{-1}$ methionine (pH 7.8); $2 \mathrm{mmol} \mathrm{L}^{-1}$ riboflavin; $0.075 \mathrm{mmol} \mathrm{L}^{-1}$ nitroblue tetrazolium (NBT) and an $10 \mu \mathrm{L}$ aliquot of enzyme extract. The production of blue formazan from NBT reduction in the presence of light was monitored by a spectrophotometer at $560 \mathrm{mmol} \mathrm{L}^{-1}$. Results were expressed in units of SOD $\mathrm{mg}^{-1}$ protein, assuming that 1 unit of SOD is the amount of enzyme required to reduce the production of blue formazan by $50 \%$. Catalase (EC 1.11.1.6) was extracted from $300 \mathrm{mg}$ of plant material ground in liquid $\mathrm{N}$ in $3 \mathrm{~mL}$ of a solution consisting of: $100 \mathrm{mmol} \mathrm{L}^{-1}$ trifluoromethyl ketone 
(pH 7.0); plus 2 mmol L-1 EDTA; $0.1 \%$ (v/v) Triton X100; $0.1 \%(\mathrm{v} / \mathrm{v}) 2$-mercaptoethanol; $20 \mathrm{mmol} \mathrm{L}^{-1}$ ascorbate; $30 \mathrm{mg}$ PVPP. An aliquot of $20 \mathrm{~L}$ of supernatant obtained by centrifugation of the homogenate at $15,000 \mathrm{~g}$ for $15 \min$ at $4{ }^{\circ} \mathrm{C}$ was used to assess enzyme activity.

The reaction medium $(3 \mathrm{~mL})$ contained $50 \mathrm{mmol} \mathrm{L}^{-1}$ TFK ( $\mathrm{pH} 7.0$ ) and $12.5 \mathrm{mmol} \mathrm{L}^{-1} \mathrm{H}_{2} \mathrm{O}_{2}$ and the reaction was initiated by adding $20 \mu \mathrm{L}$ extract. The CAT activity was determined by monitoring the drop in absorbance of hydrogen peroxide in the spectrophotometer at 280 nm (Peixoto et al., 1999). The enzymatic activity was calculated from a molar extinction coefficient of $\mathrm{H}_{2} \mathrm{O}_{2}$ $\left(\mathrm{e}=39.4 \mathrm{mmol} \mathrm{L}^{-1} \mathrm{~cm}^{-1}\right)$ and the specific CAT activity (mKat). The protein concentration was used to calculate the enzymatic activities of SOD and CAT. The leaf protein content was assessed by the Bradford (1976) method. For the preparation, $100 \mathrm{mg}$ of the dye Coomassie Brilliant Blue G-250 was dissolved in $50 \mathrm{~mL} 95 \%$ ethanol; $100 \mathrm{~mL}$ of $85 \%$ phosphoric acid was added and this diluted in $1 \mathrm{~L}$ of distilled water. To prepare bovine serum albumin (BSA), $0.88 \mathrm{~g} \mathrm{NaCl}$ in $100 \mathrm{~mL}$ of distilled $\mathrm{H}_{2} \mathrm{O}$ was used to obtain a 0.15 molar saline solution and $100 \mathrm{~mL}$ albumin. Three $100 \mathrm{~mL}$ aliquots of the extract and $5 \mathrm{~mL}$ Bradford reagent were used, readings were taken on a spectrophotometer at $595 \mathrm{~nm}$ absorbance, and a standard curve prepared to calculate the protein with bovine serum albumin.

The results were subjected to analysis of variance (ANOVA) and means compared by the Scott-Knott or Student's t-test at $\mathrm{p}<0.05$ (Steel et al., 2006). Standard deviations were calculated and the estimators of regression and Pearson correlation applied using software SISVAR (Ferreira, 2011).

\section{RESULTS AND DISCUSSION}

The electrical conductivity increased linearly proportional to increasing $\mathrm{K}_{2} \mathrm{O}$ rates, regardless of the source (Figure 1). However, electrical conductivity values were significantly higher when $\mathrm{KCl}$ was used, indicating salinity of the soil in comparison with $\mathrm{K}_{2} \mathrm{SO}_{4}$. This result proves the greater effect of soil salinization of $\mathrm{KCl}$ than $\mathrm{K}_{2} \mathrm{SO}_{4}$. The saline index of $\mathrm{K}_{2} \mathrm{SO}_{4}$ per unit $\mathrm{K}_{2} \mathrm{O}$ is equivalent to half the rate of potassium chloride (Kamburova \& Kirilov, 2008). Although the demand for $\mathrm{KCl}$ fertilizer in agriculture is great for being cheaper than other $\mathrm{K}$ sources, our data corroborate those described in the literature confirming the major effect of $\mathrm{KCl}$ in the salinization of the environment and the indication of $\mathrm{K}_{2} \mathrm{SO}_{4}$ as source with a lower saline index (Nogueira et al., 2001).

The activity of CAT (Figure 2) and SOD (Figure 3) evaluated in eggplant leaves showed different patterns according to the $\mathrm{K}$ sources in the four evaluations.
When the $\mathrm{K}$ source was $\mathrm{KCl}$, there was a positive quadratic relationship $\left(\mathrm{R}^{2}=0.74\right.$ and 0.94$)$ of CAT activity with $\mathrm{K}_{2} \mathrm{O}$ rates 30 and 60 DAT. The maximum activities were $12 \mathrm{mmol} \mathrm{L}^{-1} \mathrm{H}_{2} \mathrm{O}_{2}$ min $\mathrm{mg}$ fresh weight at $30 \mathrm{DAT}$ and 9 at $60 \mathrm{DAT}$, respectively, at 500 and $750 \mathrm{~kg} \mathrm{ha}^{-1} \mathrm{~K}_{2} \mathrm{O}$ (Figure 2a). The

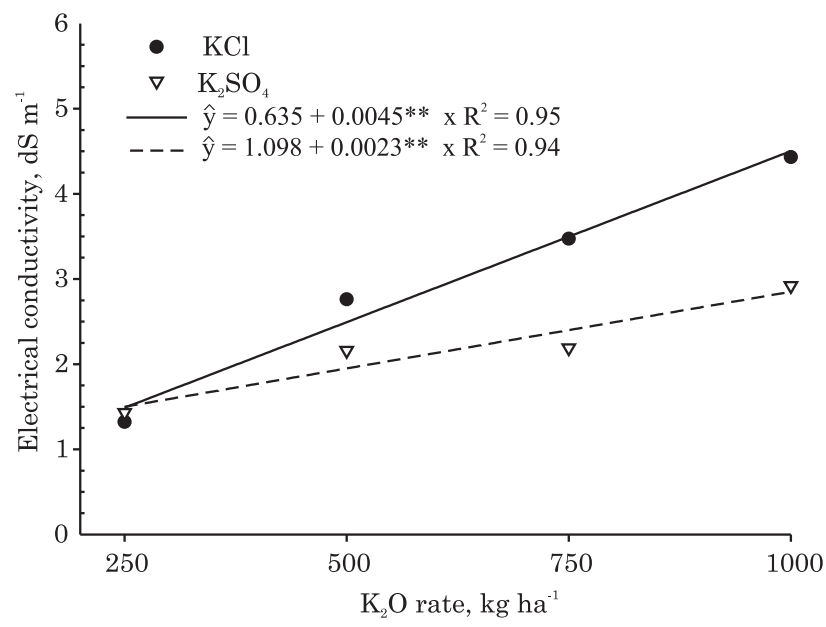

Figure 1. Effect of $K$ sources and rates on soil electrical conductivity.

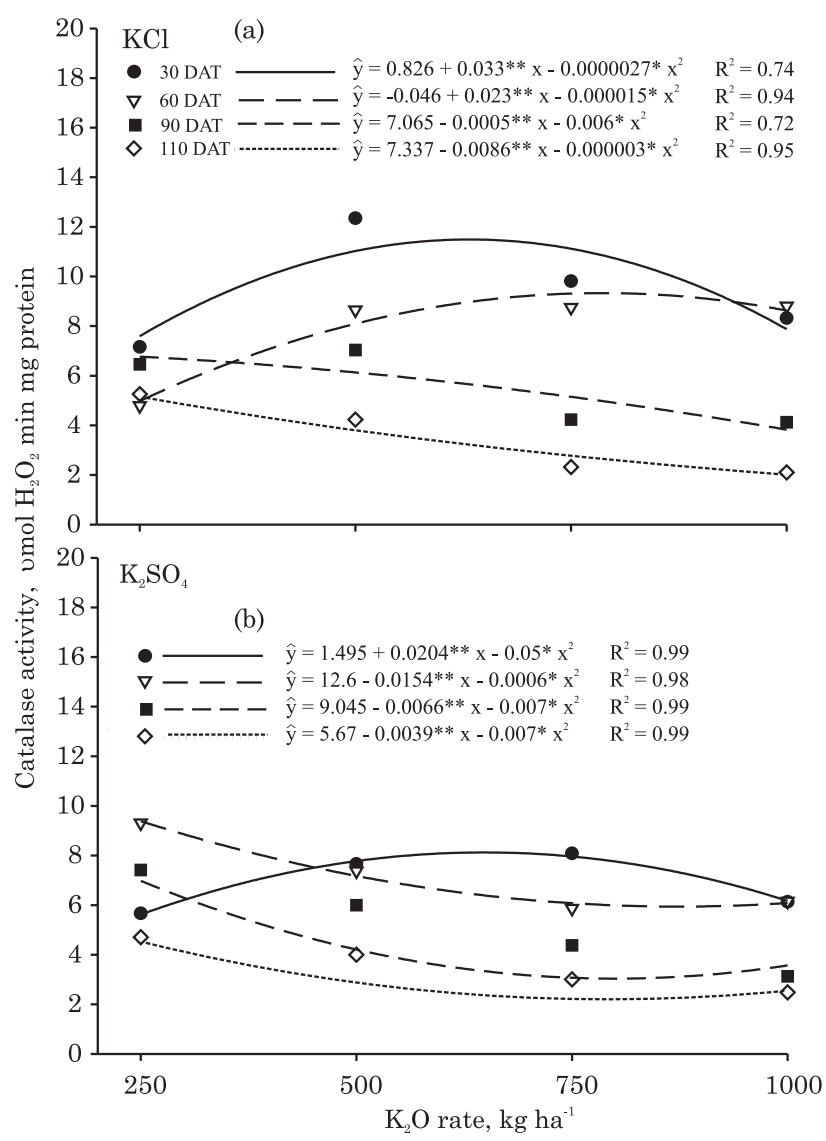

Figure 2. Effect of $\mathrm{K}$ sources and rates on catalase activity in eggplant leaves at $30,60,90$, and 110 days after transplanting (DAT). 
assessment 90 and 110 DAT showed a decrease in CAT activity with increasing $\mathrm{K}_{2} \mathrm{O}$ rates.

For $\mathrm{K}_{2} \mathrm{SO}_{4}$ as $\mathrm{K}$ source, there was a positive quadratic response of CAT enzyme activity with $\mathrm{K}_{2} \mathrm{O}$ rates only in the evaluation 30 DAT (Figure $2 \mathrm{~b}$ ). Similarly to $\mathrm{KCl}$ at 60 and $90 \mathrm{DAT}$, the CAT activity decreased with increasing K rates 60, 90 and 110 DAT. Figure 2(a,b) also show a positive response of CAT activity to $\mathrm{K}_{2} \mathrm{O}$ rates up to approximately $500 \mathrm{~kg} \mathrm{ha}^{-1}$.

These results show responses in CAT activities according to the plant age, suggesting some considerations. The first is that, whatever the source, at rates above $500 \mathrm{~kg} \mathrm{ha}^{-1} \mathrm{~K}_{2} \mathrm{O}$, the eggplants may be affected by salt excess in the plant cells, reducing enzyme activity. The other is that, after 90 DAT, topdressing with $\mathrm{K}$ sources $\left(\mathrm{KCl}\right.$ and $\left.\mathrm{K}_{2} \mathrm{SO}_{4}\right)$ is not recommendable because the plant would respond negatively to fertilization, which in addition to the financial loss could cause soil salinization. These results, indicating increased CAT activity 30 and 60 DAT, may be related to the phenological stage of the crop, with maximum growth activity in this period. In the phenological stages 90 and 110 DAT, a drop in activity was noted since the plants already entered senescence. The presence of salt in the soil has two major effects on plant growth. The first is that the high concentration in the soil solution reduces the ability of the plant to absorb water, delaying growth. This is known as the osmotic effect caused by drought or salinity. The second is that the salt may enter the transpiration stream and eventually damage the leaf cells, reducing further growth and causing a major physiological disorder (Mahajan \& Tuteja, 2005). Marques et al. (2011) demonstrated the negative effect of the sources $\mathrm{KCl}$ and $\mathrm{K}_{2} \mathrm{SO}_{4}$ on leaves of eggplants grown at different $\mathrm{K}_{2} \mathrm{O}$ concentrations.

The responses of SOD activity to $\mathrm{K}$ rates and sources are shown in figure 3(a,b). At 30 and 110 DAT using $\mathrm{KCl}$ (Figure 3a), there was a quadratic response with reduction in SOD activity up to a rate of $750 \mathrm{~kg} \mathrm{ha}^{-1} \mathrm{~K}_{2} \mathrm{O}$, above which there was an increase in enzyme activity. For $\mathrm{K}_{2} \mathrm{SO}_{4}$ (Figure $3 \mathrm{~b}$ ), the SOD activity increased linearly with increasing $\mathrm{K}_{2} \mathrm{O}$ concentrations. According to Alscher et al. (2002), within the cell, SODs are the first line of defense against AOS. These proteins belong to the metalloenzymes that protect cells from superoxide radicals by catalyzing the dismutation of $\mathrm{O}^{2-}$ in $\mathrm{O}_{2}$ and $\mathrm{H}_{2} \mathrm{O}_{2}$ (van Breusegem et al., 2001). Several studies have demonstrated the role of enzymatic antioxidant mechanisms in the protection against secondary oxidative stress induced by salinity (Rubio et al., 2009).

Regardless of the $\mathrm{K}$ sources, the protein content assessed in eggplant leaves decreased quadratically with increasing rates (Figure 4a,b). The results found in this study agree with those reported by Piza et al. (2003) for the cultivation of pineapple [Ananas comosus (L.) Merrill] in saline, where the levels of total soluble proteins decreased at all values of salinity applied. Proteolysis also provides amino acids required for cell maintenance and growth and protein degradation is also accelerated during nutritional disorders that may be caused by salinity, in order to keep the level of amino acids that would result in greater control of osmotic capacity, for amino acids are known as osmotically active compounds (Viestra, 1993).

Table 2 presents the mean values of number of leaves per plant in relation to the $\mathrm{K}_{2} \mathrm{O}$ rates, for $\mathrm{KCl}$ and $\mathrm{K}_{2} \mathrm{SO}_{4}$. The interaction for sources and rates was significant. When the $\mathrm{K}$ source was $\mathrm{K}_{2} \mathrm{SO}_{4}$, leaf production was significantly higher at 500 and $750 \mathrm{~kg} \mathrm{ha}^{-1}$. With the use of $\mathrm{KCl}$ however the differences in number of leaves were significant, according to the rate. These results indicate that despite the change in enzyme activity (SOD and CAT) and decreased protein content in eggplant leaves, the plants did not paralyze leaf production, indicating that eggplant can be grown in environments with soil salinity problems. Environmental stresses such as high temperatures, excess light, drought, and salinity are worldwide limiting to crop yields (Mittler, 2006). These conditions negatively influence plant survival and production and accumulation of biomass and grain

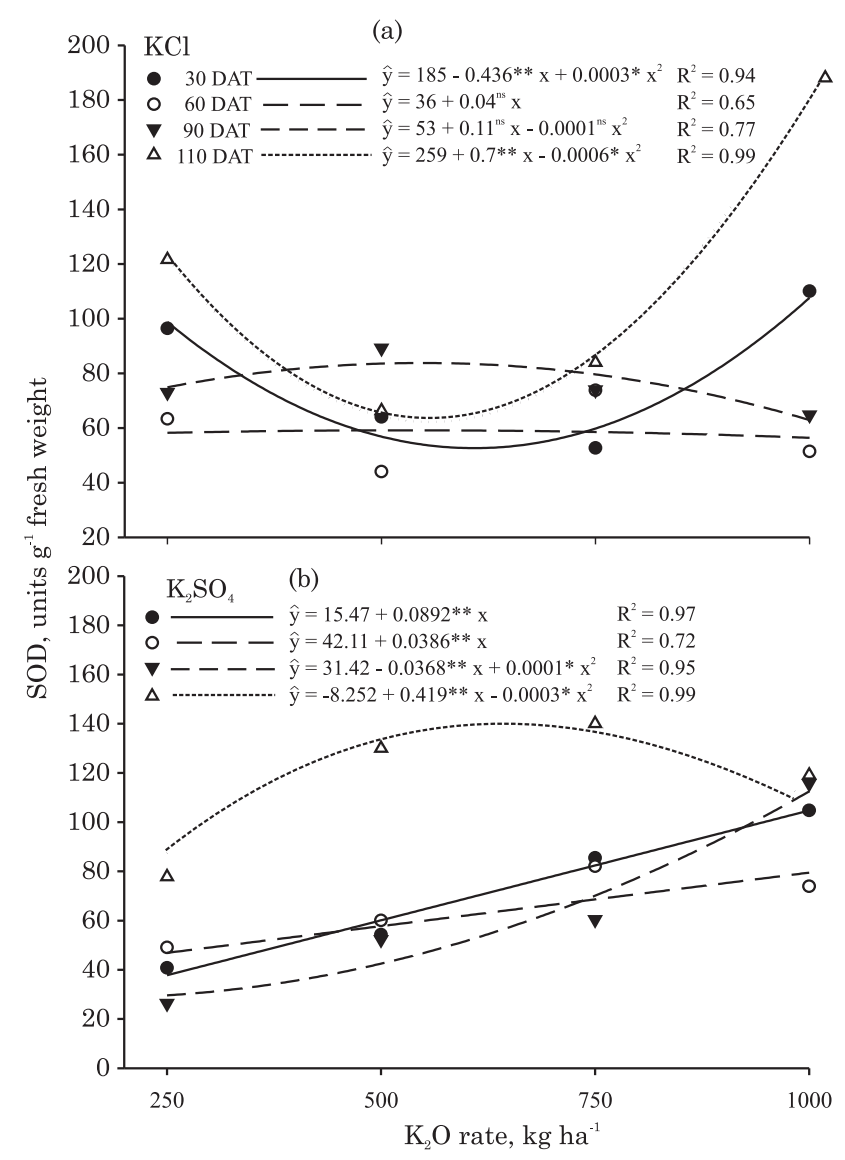

Figure 3. Effect of $K$ sources and rates on superoxide dismutase (SOD) activity in eggplant leaves at $30,60,90$, and 110 days after transplanting (DAT). 


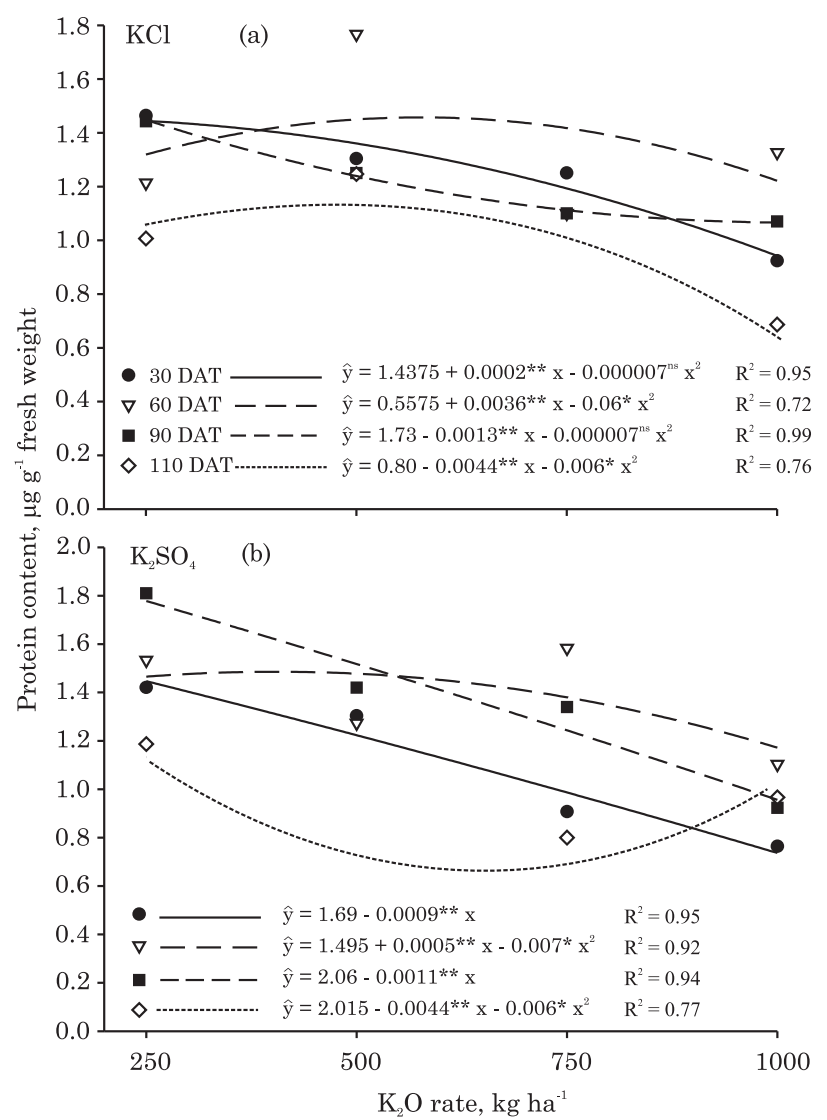

Figure 4. Effect of $\mathrm{K}$ sources and rates on protein content in eggplant leaves at 30, 60,90, and 110 days after transplanting (DAT).

Table 2. Effect of $K$ sources and rates on the number of eggplant leaves

\begin{tabular}{cccc}
\hline Rate of $\mathbf{K}_{\mathbf{2}} \mathbf{O}$ & $\mathbf{K C l}$ & $\mathbf{K}_{\mathbf{2}} \mathbf{S O}_{\mathbf{4}}$ & $\mathbf{K C l}$ \\
\hline \multirow{2}{*}{$\mathrm{kg} \mathrm{ha}^{-1}$} & \multicolumn{3}{c}{ Number of leaves } \\
\cline { 2 - 4 } 250 & $63.45 \mathrm{Aa}$ & $66.45 \mathrm{Aa}$ & 64.95 \\
500 & $67.80 \mathrm{Aa}$ & $72.95 \mathrm{Bb}$ & 70.37 \\
750 & $63.63 \mathrm{Aa}$ & $70.88 \mathrm{Bb}$ & 67.25 \\
1000 & $64.83 \mathrm{Aa}$ & $67.65 \mathrm{Aa}$ & 66.23 \\
\hline
\end{tabular}

Equal capital letters in the column and the same lowercase letters in a row do not differ from each other at the $5 \%$ by the Scott-Knott test. yield of the economically most important crops (Grover et al., 2001). Significant differences were observed 30 and $60 \mathrm{DAT}$ in the interaction of sources $(\mathrm{KCl}$ and $\left.\mathrm{K}_{2} \mathrm{SO}_{4}\right) \times \mathrm{K}_{2} \mathrm{O}$ rates $\left(250,500,750\right.$ and $1000 \mathrm{~kg} \mathrm{ha}^{-1}$ $\mathrm{K}_{2} \mathrm{O}$ ) (Table 3), noting that plant height was higher for source $\mathrm{K}_{2} \mathrm{SO}_{4}$. Although the sources ( $\mathrm{KCl}$ and $\mathrm{K}_{2} \mathrm{SO}_{4}$ ) affected the SOD and CAT activity, protein content and plant growth of eggplant (Tables 2 and $3)$, it was observed that plant death was not increased at the sources and concentrations tested. The negative effects may have been mitigated by the plant architecture in bush form with various bifurcations, facilitating salt dilution in the plant tissues.

\section{CONCLUSIONS}

1. The potential of $\mathrm{KCl}$ to salinize soils is higher than that of $\mathrm{K}_{2} \mathrm{SO}_{4}$.

2. High rates of $\mathrm{KCl}$ as well as of $\mathrm{K}_{2} \mathrm{SO}_{4}$ adversely affected the enzyme activities of catalase (CAT) and superoxide dismutase (SOD) as well as leaf protein contents in eggplant.

3. The potential of $\mathrm{KCl}$ to reduce the enzyme activities of SOD and CAT, leaf protein content and the development of eggplants is higher than that of $\mathrm{K}_{2} \mathrm{SO}_{4}$.

\section{ACKNOWLEDGEMENT}

The first author wishes to thank the Brazilian Federal Agency for Support and Evaluation of Graduate Education (CAPES) for a postgraduate scholarship.

\section{LITERATURE CITED}

ABBASI, G.H.; AKHTAR, J.; ANWAR-UL-HAQ, M.; ALI, S.; CHEN, Z. \& MALIK, W. Exogenous potassium differentially mitigates salt stress in tolerant and sensitive maize hybrids. Pakistan J. Bot., 46:135-146, 2014.

Table 3. Effect of $K$ rates and sources on plant height at 30, 60, 90 and 110 days after transplanting (DAT)

\begin{tabular}{|c|c|c|c|c|c|c|c|c|}
\hline \multirow{2}{*}{ Rate of $\mathrm{K}_{2} \mathrm{O}$} & $\mathrm{KCl}$ & $\mathrm{K}_{2} \mathrm{SO}_{4}$ & $\mathrm{KCl}$ & $\mathrm{K}_{2} \mathrm{SO}_{4}$ & $\mathrm{KCl}$ & $\mathrm{K}_{2} \mathrm{SO}_{4}$ & $\mathrm{KCl}$ & $\mathrm{K}_{2} \mathrm{SO}_{4}$ \\
\hline & \multicolumn{2}{|c|}{30 DAT } & \multicolumn{2}{|c|}{60 DAT } & \multicolumn{2}{|c|}{90 DAT } & \multicolumn{2}{|c|}{110 DAT } \\
\hline \multicolumn{9}{|l|}{$\mathrm{kg} \mathrm{ha} \mathrm{h}^{-1}$} \\
\hline 250 & $14.50 \mathrm{Aa}$ & $16.60 \mathrm{Aa}$ & $76.80 \mathrm{Aa}$ & $78.20 \mathrm{Aa}$ & $132.60 \mathrm{Aa}$ & $126.00 \mathrm{Aa}$ & $144.30 \mathrm{Aa}$ & $140.30 \mathrm{Aa}$ \\
\hline 500 & $14.00 \mathrm{Aa}$ & $19.40 \mathrm{Ab}$ & $76.80 \mathrm{Aa}$ & $79.00 \mathrm{Aa}$ & $119.40 \mathrm{Aa}$ & $132.40 \mathrm{Ab}$ & $152.90 \mathrm{Aa}$ & $152.20 \mathrm{Aa}$ \\
\hline 750 & $11.40 \mathrm{Aa}$ & $22.10 \mathrm{Ab}$ & $70.20 \mathrm{Aa}$ & $80.80 \mathrm{Ab}$ & $127.80 \mathrm{Aa}$ & $130.60 \mathrm{Aa}$ & $146.90 \mathrm{Aa}$ & $143.60 \mathrm{Aa}$ \\
\hline 1000 & $13.40 \mathrm{Aa}$ & $16.72 \mathrm{Ab}$ & $78.40 \mathrm{Aa}$ & $82.00 \mathrm{Ab}$ & $123.60 \mathrm{Aa}$ & $127.20 \mathrm{Aa}$ & $143.04 \mathrm{Aa}$ & $143.16 \mathrm{Aa}$ \\
\hline CV (\%) & 17.92 & 17.92 & 9.62 & 9.62 & 8.59 & 8.59 & 10.51 & 10.51 \\
\hline
\end{tabular}

Same capital letters in the column and same lowercase letters in the row do not differ from each other at the $5 \%$ by the Scott-Knott test. 
ALSCHER, R.G.; ERTURK, N. \& HEALT, L.S. Role of superoxide dismutase (SODs) in controlling oxidative stress in plants. J. Exp. Bot., 53:1331-1341, 2002.

APEL, K. \& HIRT, H. Reactive oxygen species: Metabolism, oxidative stress, and signal transduction. Ann. Rev. Plant Biol., 55:373-399, 2004.

BOSE, J.; RODRIGO-MORENO, A. \& SHABALA, S. ROS homeostasis in halophytes in the context of salinity stress tolerance. J. Exp. Bot., 65:1241-1257, 2014.

BRADFORD, M.M. A rapid and sensitive method for quantitation of microgram quantities of protein utilizing the principle of protein-dyebinding. Anal. Biochem., 72:248-254, 1976.

CHAVES, M.M.; PEREIRA, J.S.; MAROCO, J.; RODRIGUES, M.L.; RICARDO, C.P.P.; OSORIO, M.L.; CARVALHO, I.; FARIA, T. \& PNHEIRO, C. How plants cope with water stress in the field. Photosynthesis and growth. Ann. Bot., 89:907-916, 2002.

CUNHA, A.R. \& MARTINS, D. Classificação climática para os municípios de Botucatu e São Manoel, SP. Irriga, 14:1-11, 2009.

EMPRESA BRASILEIRA DE PESQUISA AGROPECUÁRIA EMBRAPA. Centro Nacional de Pesquisa de Solos. Manual de métodos de análises de solo. Rio de Janeiro, 1997. $212 \mathrm{p}$.

ERNANI, P.R.; ALMEIDA, J.A. \& SANTOS, F.C. Potássio. In: NOVAIS, R. F.; ALVAREZ V, V. H.; BARROS, N.F.B.; FONTES, R.L.F.; CANTARUTTI, R.B. \& NEVES, J.C.L., eds. Fertilidade do solo. Viçosa, MG, SBCS, 2007. p.551594.

FERREIRA, D. SISVAR: A computer statistical analysis system. Ci. Agrotec., 35:1039-1042, 2011.

GIANNOPOLITIS, C.N. \& RIES, S.K. Superoxide dismutases. I: Occurrence in higher plants. Plant Physiol., 59:309314, 1977.

GROVER, A.; KAPOOR, A.; LAKSHMI, O.S.; AGARWAL, S.; SAHI, C.; KATIYAR-AGARWAL, S.; AGARWAL, M. \& DUBEY, H. Understanding molecular alphabets of the plant abiotic stress responses. Curr. Sci., 80:206-216, 2001.

KAMBUROVA, K. \& KIRILOV, P.L. Calculating the salt index of $\mathrm{pK}$ and NPK liquid fertilizers from potassium phosphates. J. Chem. Technol. Metal., 43:227-230, 2008.

KHADRI, M.; TEJERA, N.A. \& LLUCH, C. Sodium chlorideABA interaction in two common bean (Phaseolus vulgaris) cultivars differing in salinity tolerance. Environ. Exp. Bot., 60:211-218, 2006.

MAHAJAN, S. \& TUTEJA, N. Cold, salinity and drought stresses: An overview. Arch. Biochem. Biophys., 444:139$158,2005$.
MALAVOLTA, E. Manual de nutrição mineral de plantas. São Paulo, Agronômica Ceres, 2006. 638p.

MARSCHNER, H. Mineral nutrition of higher plants. San Diego, Academic Press, 1995. 889p.

MARQUES, D.J.; BROETTO, F.; SILVA, E.C.; FREITAS, J.M.N.; LOBATO, A.K.S. \& ALVES, G.A.R.A. Changes in leaf proline and fruit production induced by potassium stress in eggplant. J. Food Agric. Environ., 9:91-194, 2011.

MITTLER, R. Abiotic stress, the field environment and stress combination. Trends Plant Sci., 11:15-19. 2006.

MOLLER, I.M.; JENSEN, P.E. \& HANSSON, A. Oxidative modifications to cellular components in plants. Ann. Rev. Plant Biol., 58:459-481, 2007.

NOGUEIRA, F.D.; SILVA, E.B.E. \& GUIMARÃES, P.T.G. Adubação potássica do cafeeiro: Sulfato de potássio. Washington, SOPIB, 2001. 81p.

PEIXOTO, P.H.P.; CAMBRAIA, J.; SANT'ANNA, R.; MOSQUIM, P.R. \& MOREIRA, M.A. Aluminum effects on lipid peroxidation and the activities of enzymes of oxidative metabolism in sorghum. R. Bras. Fisiol. Veg., 11:137-143, 1999.

PIZA, I.M.T.; LIMA, G.P.P. \& BRASIL, O.G. Atividade de peroxidase e níveis de proteínas em plantas de abacaxizeiro micropropagadas em meio salino. R. Bras. Agroci., 9:361-366, 2003.

RAIJ, B.van; CANTARELLA, H.; QUAGGIO, J.A. \& FURLANI, A.M.C., eds. Recomendações de adubação e calagem para o estado de São Paulo. Campinas, Instituto Agronômico de Campinas, 1996. 285p. (Boletim Técnico, 100)

RUBIO, M.C.; BUSTOS-SANMAMED, P.; CLEMENTE, M.R. \& BECANA, M. Effects of salt stress on the expression of antioxidant genes and proteins in the model legume Lotus japonicus. New Phytol., 181:851-859, 2009.

STEINECK, O. \& HAEDER, H.E. The effect of potassium on growth and yield components of plants. In: CONGRESS INTERNATIONAL OF THE POTASH INSTITUTE, 11., Bern, 1978. Proceedings... Bern, IPI, 1978. p.165-187.

STEEL, R.G.D.; TORRIE, J.H. \& DICKEY, D.A. Principles and procedures of statistics: A biometrical approach. 3.ed. Moorpack, CA, Academic Internet Publishers, 2006. 666p.

SOIL SCIENCE SOCIETY OF AMERICA - SSSA. Glossary of soil science terms. Madison, 2008. 88p.

van BREUSEGEM, F.; VRANOVA, E.; DAT, J.F. \& INZE, D. The role active oxygen species in plant signal transduction. Plant Sci., 161:405-414, 2001.

VIESTRA, R.D. Protein degradation in plants. Ann. Rev. Plant Physiol., 44:385-410, 1993.

WUZHONG, N. Yield and quality of fruits of solanaceous crops as affected by potassium fertilization. Better Crops, $13: 6-8,2002$ 